\title{
Hak Istri dalam Rujuk Menurut Fikih Empat Mazhab dan Kompilasi Hukum Islam (Perspektif Maqasid Al-Shari'ah)
}

\author{
Muhammad Za'im Muhibbulloh, Dewi Niswatin Khoiroh, A. Rofi'ud \\ Darojad \\ Institut Agama Islam Nahdlatul Ulama Tuban \\ E-mail: zaim19991@gmail.com, ani342305@gmail.com, rafiud9933@gmail.com
}

\begin{abstract}
Abstrak: Rujuk dalam hukum Islam sah tanpa sepengetahuan atau sepertujuan istri. Imam-imam Mazhab dalam literatur kitab fikih, semuanya sepakat bahwa tidak diperlukan izin istri dalam proses rujuk, sehingga seorang suami berhak merujuk istrinya kapan saja selama dia masih dalam masa iddah tanpa kerelaan seorang istri sedangkan dalam Kompilasi Hukum Islam (KHI), rujuk sah hukumnya apabila sudah mendapat izin dari istri tertuang dalam pasal $165 \mathrm{KHI}$ yang bunyinya demikian "Rujuk yang dilakukan tanpa persetujuan bekas istri, dapat dinyatakan tidak sah dengan putusan Pengadilan Agama". Penelitian ini termasuk penelitian pustaka, bersifat kualitatif deskriptif analitik yang berusaha menganalisanya sehingga mendapatkan hasil yang komprehensif dan mendalam untuk mengambil kesimpulan yang selaras dengan pokok masalah menggunakan teori Maqasid al-Shari'ah. Hasil penelitian ini menyimpulkan bahwa, izin istri diperlukan dalam rujuk agar selaras dengan tujuan-tujuan syari'ah (Maqasid al-Shari'ah): Mengatur hubungan laki-laki dan perempuan, Menjaga keturunan, Menciptakan keluarga yang sakinah, mawaddah, wa rahmah, Menjaga garis keturunan, Menjaga keberagaman dalam keluarga, Mengatur pola hubungan yang baik dalam keluarga dan Mengatur aspek finansial keluarga.

Kata Kunci Rujuk, Maqasid al-Shari'ah, hak istri.
\end{abstract}

\section{Pendahuluan}

Rujuk secara etimologi adalah kembali, sedangkan secara terminologi rujuk adalah kembalinya seorang istri pada suatu perkawinan ketika masih dalam masa iddah selain talak bäin dengan cara-cara tertentu. ${ }^{1}$ Rukun atau unsur yang disepakati oleh ulama dalam rujuk adalah ucapan rujuk, mantan suami yang merujuk dan mantan istri yang dirujuk. ${ }^{2}$

\footnotetext{
${ }^{1}$ Muhāmmad bin Qashīm Al-Ghazī, Fath al-Qorìb, (Surabaya: Nurul Huda, t.t.), hlm. 48 ${ }^{2}$ Amir Syarifuddin, Hukum Perkawinan Islam di Indonesia, (Jakarta: Prenada Media, 2007), hlm. 341
} 
Dari definisi di atas dapat dijadikan prinsip, bila rujuk dilakukan di luar masa iddah maka tidak sah, dan bila kembalinya dilakukan pada talak bāin maka tidak dinamakan dengan rujuk. ${ }^{3}$ Imam-imam Mazhab dalam literatur kitab fikih, semuanya sepakat bahwa tidak diperlukan izin istri dalam proses rujuk, sehingga seorang suami berhak merujuk istrinya kapan saja selama istrinya masih dalam masa iddah dan keberlakuan hukum tersebut bisa tetap berjalan atau sah meskipun tanpa kerelaan seorang istri. ${ }^{4}$

Konsep rujuk yang demikian bertentangan dengan konsep rujuk yang terdapat dalam KHI, dimana rujuk baru bisa terjadi atau sah hukumnya bila sudah mendapat izin dari istri. Hal tersebut sesuai dengan pasal 165 KHI yang bunyinya demikian "Rujuk yang dilakukan tanpa persetujuan bekas istri, dapat dinyatakan tidak sah dengan putusan Pengadilan Agama". ${ }^{5}$

Untuk menyelesaikan pertentangan diatas, peneliti menggunakan salah satu teori hukum Islam yakni teori Maqasid al-Shari'ah Djamaluddin Athiyah sebagai pisau analisa dalam penelitian ini.

\section{Metode Penelitian}

Penelitian ini termasuk penelitian pustaka, yakni tentang hak istri dalam rujuk menurut fikih empat mazhab dan Kompilasi Hukum Islam perspektif Maqasid al-Shari'ah, bersifat kualitatif deskriptif analitik yang berusaha menganalisanya sehingga mendapatkan hasil yang komprehensif dan mendalam untuk mengambil kesimpulan yang selaras dengan pokok masalah menggunakan teori Maqasid al-Shari'ah.

Sumber Primer dalam penelitian ini adalah data tentang rujuk dan Maqasid al-Shari'ah. Dalam hal ini adalah: 1) Muhammad ibn Idrīs, al-Um, 2) Muhammad ibn Abī Sahal al-Sarkhasī, al-Mabsūt, 3) Malik ibn Anas, alMudawwanah al-Kubrö, 4) Abdulloh ibn Quda>mah, al-Kaāfï, 5) Kompilasi Hukum Islam, 6) Jamaluddin Athiyah, Nahwa Taf'il Maqasid al-Shari'ah. Sedangkan sumber data sekunder dalam penelitian ini adalah beberapa data tambahan tentang rujuk dan Maqasid al-Shari'ah dalam kitab-kitab dan buku-buku, baik secara langsung ataupun tidak langsung.

Untuk menunjang penulisan jurnal ini, peneliti menggunakan metode dokumentasi, ini digunakan untuk mencari data mengenai hal-hal atau

\footnotetext{
3Sayyid Sābiq, Fiqh al-Sunnah, Vol 2 (Mesir: Dār al-Hadīś, 2009), hlm. 177

${ }^{4}$ Sayyid Sābiq, Al-Sunnah, Vol 2, hlm. 178. Dan Juga Lihat, Ibn Rusyd, Bidāyah, vol 2, hlm. 63

${ }^{5}$ Undang-Undang Peradilan Agama Dan Kompilasi Hukum Islam (Yogyakarta: Graha Pustaka, t.t.), hlm. 185
} 
variabel yang berupa catatan, transkrip, buku, surat kabar, majalah, agenda ${ }^{6}$,yang berhubungan dengan konsep rujuk. Adapun teknik atau metode pengumpulan data dalam penelitian ini, sebagai berikut:

Metode dokumentasi adalah metode pengumpulan data dengan melihat atau menganalisis dokumen-dokumen yang dibuat oleh subjek sendiri atau oleh orang lain oleh subjek. ${ }^{7}$ Dalam penelitian ini, peneliti akan mengumpulkan data dari dokumen yang sudah ada, sehingga penulis dapat memperoleh catatan-catatan yang berhubungan dengan penelitian, yaitu: data tentang rujuk yang ada dalam fikih dan KHI serta data tentang konsep Maqasid al-Shari'ah.

Teknik analisis data dalam penelitian ini bersifat kualitatif dengan penalaran deduktif-induktif. Penalaran deduktif ${ }^{8}$ untuk menjabarkan hal yang bersifat normatif yang ada dalam sumber primer yang digunakan, yaitu konsep rujuk yang ada dalam pandangan ulama fikih dan KHI. Kemudian ditelusuri bagaimana penerapan Maqasid al-Shari'ah dalam keduanya dengan menggunakan pola berfikir induktif ${ }^{9}$. Setelah itu dilakukan pemeriksaan untuk memilih data mana yang sesuai dengan masalah yang diteliti, dilanjutkan dengan mengklasifikasikan data dengan cara menyusun data yang diperoleh ke dalam permasalahan yang berbeda-beda yang bertujuan untuk mempermudah pembahasan. Setelah data terkumpul maka diadakan pengecekan data atau verifikasi data untuk menguji validitas data yang diperoleh dan dilanjutkan dengan menganalisis data yang telah terkumpul.

\section{Hasil dan Pembahasan}

Terkait hak istri dalam rujuk, penelitian ini mencoba memaparkan dua perspektif yang mana memiliki ruangnya sendiri. Dua perspektif inilah yang nantinya akan menjadi pokok pembahasan apabila dipadukan dengan teori Maqasid al-Shari'ah. Dua perspektif itu ialah:

\footnotetext{
6 Suharsimin Arikunto, Prosedur Penelitian Suatu Pendekatan Praktik, (Jakarta: PT RinekaCipta, 2006), hlm. 231

${ }^{7}$ Haris Herdiansyah, Metodologi Penelitian Kualitatif, (Jakarta: Salemba Humanika, 2010), hlm. 143

8 Penarikan kesimpulan dari keadaan yang umum; penyimpulan dari yang umum ke yang khusus. Kamus Besar Bahasa Indonesia (KBBI).

9 Penarikan kesimpulan berdasarkan keadaan yang khusus untuk diperlakukan secara umum; penentuan kaidah umum berdasarkan kaidah khusus.Kamus Besar Bahasa Indonesia (KBBI).
} 


\section{Perspektif Fikih Empat Madzhab}

Sebelum membahas tentang hak istri dalam rujuk, peneliti memaparkan definisi rujuk menurut empat Madzhab, sebagai berikut:

a. Menurut Hanafizyah, rujuk ialah melangsungkan hak kepemilikan istri tanpa ada gantian dalam masa iddah. Redaksi "tanpa ada gantian" ini menunjukkan tentang kembalinya hak kepemilikan istri tanpa adanya akad baru yakni talak yang dilontarkan suami adalah talak raj'i.

b. Menurut Malikiyah, rujuk ialah kembalinya istri yang telah ditalak, kepada perlindungan suami, tanpa ada pembaharuan akad nikah. Meskipun dalam pengertian tidak mengungkapkan antara talak bāin dan talak raj'i, namun redaksi "tanpa membutuhkan pembaharuan akad nikah", sudah mengecualikan kembalinya istri dengan akad baru, maka itu dinamakan talak bāin. Sedangkan bila tanpa akad yang baru itu hanya pada talak raj' $i^{10}$

c. Menurut Shäfi'ìyah, rujuk ialah mengembalikan wanita dalam satu ikatan perkawinan, dari talak yang bukan talak ba'in selama masa iddah. Yang dimaksud redaksi talak yang bukan talak ba'in ialah talak raj'i.Menurut Hanabillah, rujuk ialah kembalinya perempuan yang ditalak selain bain kepada perlindungan suami tanpa ada akad. ${ }^{11}$

Pengertian diatas menunjukkan bahwasanya rujuk itu mengembalikan kepemilikan istri yang sebelumnya putus dikarenakan suami mentalak istri dengan talak raj'i.

Suami memiliki hak untuk merujuk istrinya yang telah ditalak raj'i selama istri masih dalam masa iddah, adapun masa iddah berbeda tergantung keadaan istri ketika ditalak, ada yang tiga bulan, ada yang empat bulan lebih sepuluh hari, ada yang sampai melahirkan. ${ }^{12}$

Adapun rukun dan syarat-syarat rujuk adalah hal yang harus dipenuhi untuk terlaksananya sebuah perbuatan rujuk tersebut. ${ }^{13}$ Diantara rukun dan syarat-syarat rujuk tersebut adalah sebagai berikut :

a. Sighat (lafaz), sighat ada 2 (dua), yaitu :

1) Terang-terangan (sharih), misalnya dikatakan, "Saya kembali kepada isteri saya" atau "Saya ruju'ee padamu". Yang dimaksud sighat yang sharih ialah sighat yang hanya menunjukkan arti

\footnotetext{
${ }^{10}$ Al-Jazīīi, Al-Madhāhib Al-Arba'ah, Vol. 4, hlm. 330

${ }^{11}$ Al-Jazīiīi, Al-Madhähib Al-Arba'ah, Vol. 4,hlm. 329

${ }^{12} \mathrm{Abu}$ Bakar bin Ali, al-Jauharah al-nìrah, (tt: al-Khoiriyah, $\left.1322 \mathrm{H}.\right)$, hlm. 50

${ }^{13}$ Amir Syarifuddin, Hukum Pernikahan di Indonesia antara Figh Munakahat dan Undangundang Pernikahan, (Jakarta : Kencana, 2006), hlm. 341
} 
rujuk tidak yang lain sehingga ketika sighat itu diucapkan maka tidak ada maksud lain selain rujuk. Jika suami mengucapkan sighat sharih maka dapat diketahui bahwasanya ia menghendaki untuk rujuk kepada istrinya.

2) Melalui sindiran, misalnya "Saya pegang engkau" atau "Saya kawin engkau" dan sebagainya, yaitu dengan kalimat yang boleh dipakai untuk ruju" atau untuk yang lainnya. Yang dimaksud sighat sindiran ialah sighat yang mengandung arti selain rujuk sehingga ketika sighat itu diucapkan maka masih membutuhkan pernyataan dari suami apakah yang ia kehendaki ketika mengucapkan sighat tersebut merujuk istrinya atau tidak. Di syariatkan ucapan itu tidak bertaqlid, berarti tidak digantungkan, misalnya : "Aku ruju"ee engkau jika engkau mau", ruju" semacam ini tidak sah walaupun isterinya mau. Rujuk yang terbatas waktunya juga tidak sah, misalnya : "Aku ruju" engkau sebulan". ${ }^{14}$

b. Istri (perempuan yang dirujuk), adapun syarat sahnya rujuk bagi perempuan yang dirujuk itu adalah :

1) Perempuan itu adalah istri yang sah dari laki-laki yang merujuk. Tidak sah merujuk perempuan yang bukan istrinya. ${ }^{15}$ Maksud syarat tersebut ialah perempuan yang dirujuk itu adalah benarbenar istrinya yang sah bukan istri orang lain karena tidak ada hak bagi laki-laki untuk merujuk perempuan yang bukan istrinya.

2) Istri yang tertentu, kalau suami menalak beberapa istrinya, kemudian ia ruju' kepada salah seorang dari mereka dengan tidak ditentukan siapa yang dirujukkan, maka ruju'nya itu tidah sah. Ketika suami memiliki istri lebih dari satu kemudian ia mentalak istri-istrinya, ketika ia menghendaki merujuk salah satu dari istriistrinya maka ia harus menentukan siapa yang ia kehendaki untuk dirujuk, apakah istri pertama, kedua, ketiga atau keempat.

3) Talaknya adalah talak raj'i. Talak raj'i berarti talak yang telah dilontarkan suami adalah talak satu atau talak dua karena ketika suami melontarkan talak ketiga itu dinamakan talak ba'in yang mana jika demikian tidak cukup hanya mengucapkan rujuk untuk mengembalikan kepemilikan istri tapi harus ada muhallil.

${ }^{14}$ Moh. Rifaei, Fiqih Islam Lengkap, (Semarang: PT. Karya Toha Putra, 1978), hlm. 505

${ }^{15}$ Amir Syarifuddin, hlm. 341 
4) Ruju' itu terjadi sewaktu istri masih dalam masa iddah. Apabila masa iddahnya telah berakhir, maka putuslah hubungannya dan dengan sendirinya istri tersebut tidak boleh lagi dirujuk. ${ }^{16}$ Ketika suami menghendaki untuk merujuk istrinya maka diharuskan istri masih dalam masa iddah sehingga ketika masa iddah istri habis atau istri tidak memiliki masa iddah seperti halnya istri yang belum pernah dijima' maka tidak ada hak bagi suami untuk merujuk istrinya.

c. Suami. Ruju' ini dilakukan oleh suami atas kehendaknya sendiri (bukan dipaksa), dan suami tersebut juga telah menikahi istrinya itu dengan nikahyang sah. ${ }^{17}$

Mengenai kerelaan istri dalam rujuk, empat imam mazhab sepakat bahwa hak rujuk itu hanya milik suami, sehingga dalam pelaksanaannya meskipun rujuk tanpa mendapatkan izin dari istri maka itu masih dianggap sah, karena rujuk merupakan hak prioritas seorang suami. ${ }^{18}$

\section{Perspektif Kompilasi Hukum Islam}

Dalam Hukum Perdata Islam di Indonesia, prosedur tata cara rujuk diatur tidak semudah seperti apa yang telah dikonsepkan para ulama fikih terdahulu, ada beberpa prosedur tambahan yang harus dilakukan seseorang yang ingin melakukan rujuk. Dimana hal tersebut telah diatur dalam Peraturan Mentrei Agama (Permenag) RI Nomor 3 Tahun 1975 tentang Kewajiban Pegawai Pencatat Nikah dan Tata Kerja Pengadilan Agama dalam melaksanakan Peraturan Perundang-undangan Perkawinan bagi yang beragama Islam, rujuk diatur dalam pasal 32, 33, 34, dan 38. Kemudian Permenag RI tersebut dikuatkan dalam KHI pasal 167 sampai dengan pasal 169.19

\section{Pasal 167}

(1) Suami yang hendak merujuk isterinya datang bersama-sama isterinya ke Pegawai Pencatat Nikah atau Pembantu Pegawai Pencatat Nikah yang mewilayahi tempat tinggal suami isteri dengan membawa penetapan tentang terjadinya talak dan surat keterangan lain yang diperlukan.

\footnotetext{
${ }^{16}$ Amir Syarifuddin, hlm. 341

${ }^{17}$ Amir Syarifuddin, hlm. 341

${ }^{18}$ Imām Shamsu al-Dīn abu Bakar Muhammad, Al-Mabsuț li al-Sarkhasi, Vol 5 (Lebanon : Beirut, 2000), hlm. 270.Lihat juga, Ibn Rusyd, Bidāyah, hlm. 63

${ }^{19}$ Ahmad Rofiq, Hukum Perdata Islam Di Indonesia (Jakarta: Rajagrafindo Persada, 2013), hlm. 256
} 
(Dalam Pasal 32 ayat (1) Permenag RI No. 3 Tahun 1975 hanya menyebut PPN atau P3NTR yang mewilayahi tempat tinggal Istri).

(2) Rujuk dilakukan dengan persetujuan isteri dihadapan Pegawai Pencatat Nikah atau Pembantu Pegawai Pencatat Nikah.

(3) Pegawai Pencatat Nikah atau Pembantu Pegawai Pencatat Nikah memeriksa dan meyelidiki apakah suami yang akan merujuk itu memenuhi syarat-syarat merujuk menurut hukum munakahat, apakah rujuk yang akan dilakukan masih dalam iddah talak raj'i, apakah perempuan yang akan dirujuk itu adalah isterinya.

(4) Setelah itu suami mengucapkan rujuknya dan masing-masing yang bersangkutan besrta saksi- saksi menandatangani Buku Pendaftaran Rujuk.

(5) Setelah rujuk itu dilaksanakan, Pegawai Pencatat Nikah atau Pembantu Pegawai Pencatat Nikah menasehati suami isteri tentang hukum-hukum dan kewajiban mereka yang berhubungan dengan rujuk. ${ }^{20}$

Mengenai pembentukan ketentuan yang ada pada Pasal 167 ayat (1) sampai dengan ayat (3) KHI, hal itu ditempuh agar terciptannya ketertiban porsesi rujuk bagi masyarakat Islam di Indonesia. Ketertiban di sini menyangkut tujuan dari Hukum Islam sendiri, yaitu menciptakan kemaslahatan bagi masyarakat. Sebab, apabila ada permasalahan dikemudian harinya, maka ketertiban administratif tersebut, dapat menjadi bukti yang otentik akan terjadinya rujuk, sekaligus dapat menghindarkan ketidakpastian status bagi wanita dan anak-anak. ${ }^{21}$ Karena nikah hampir sama dengan mu'amalah, maka pencatatan sebagai bukti persaksian bila ada permasalahan nantinya sesuai dengan firman Allah dalam surat al-Baqarah ayat 282. Sebagaimana berikut:

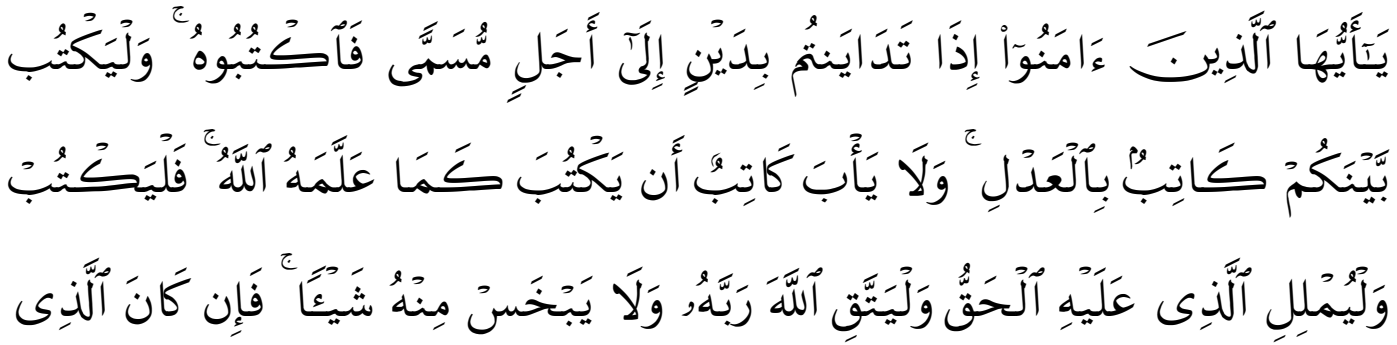

\footnotetext{
${ }^{20}$ KHI Pasal 167, lihat juga Permenag No 3 Tahun 1975 tentang Kewajiban Pegawai Pencatat Nikah dan Tata Kerja Pengadilan Agama dalam melaksanakan Peraturan Perundang-undangan Perkawinan bagi yang beragama Islam Pasal 32.

${ }^{21}$ Ahmad Rofiq, Pembaruan Hukum Islam di Indonesia (Yogyakarta: Gama Media, 2001), hlm.109
} 


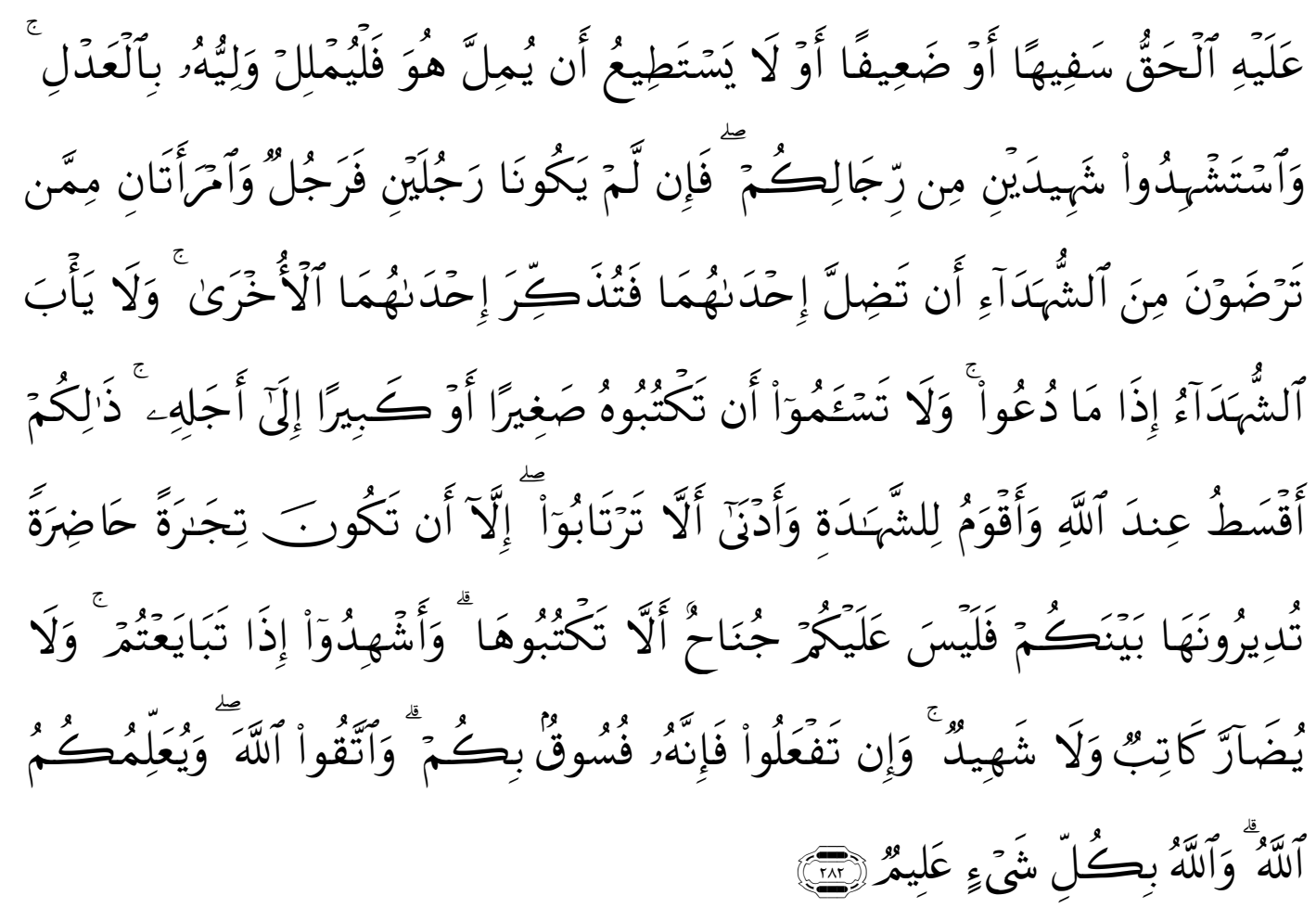

"Hai orang-orang yang beriman, apabila kamu bermu'amalah tidak secara tunai untuk waktu yang ditentukan, hendaklah kamu menuliskannya. dan hendaklah seorang penulis di antara kamu menuliskannya dengan benar. dan janganlah penulis enggan menuliskannya sebagaimana Allah mengajarkannya, meka hendaklah ia menulis, dan hendaklah orang yang berhutang itu mengimlakkan (apa yang akan ditulis itu), dan hendaklah ia bertakwa kepada Allah Tuhannya, dan janganlah ia mengurangi sedikitpun daripada hutangnya. jika yang berhutang itu orang yang lemah akalnya atau lemah (keadaannya) atau Dia sendiri tidak mampu mengimlakkan, Maka hendaklah walinya mengimlakkan dengan jujur. dan persaksikanlah dengan dua orang saksi dari orang-orang lelaki (di antaramu). jika tak ada dua oang lelaki, Maka (boleh) seorang lelaki dan dua orang perempuan dari saksi-saksi yang kamu ridhai, supaya jika seorang lupa Maka yang seorang mengingatkannya. janganlah saksi-saksi itu enggan (memberi keterangan) apabila mereka dipanggil; dan janganlah kamu jemu menulis hutang itu, baik kecil maupun besar sampai batas waktu membayarnya. yang demikian itu, lebih adil di sisi Allah dan lebih menguatkan persaksian dan lebih dekat kepada tidak (menimbulkan) keraguanmu. (Tulislah mu'amalahmu itu), kecuali jika mu'amalah itu perdagangan tunai yang kamu jalankan di antara kamu, Maka tidak ada dosa bagi kamu, (jika) kamu tidak menulisnya. dan persaksikanlah apabila kamu berjual beli; dan janganlah penulis dan saksi saling sulit menyulitkan. 
jika kamu lakukan (yang demikian), Maka Sesungguhnya hal itu adalah suatu kefasikan pada dirimu. dan bertakwalah kepada Allah; Allah mengajarmu; dan Allah Maha mengetahui segala sesuatu". ${ }^{22}$

Pentingnya saksi dalam rujuk sebagaimana yang tertuang dalam pasal 167 ayat (4) KHI, untuk keterangannya sudah dijelaskan pada pasal sebelumnya. Kesimpulannya ada dua kalangan ulama mazhab yang mensyaratkan adanya saksi dalam rujuk, yakni ulama mazhab Hanafiyah dan Shäfi'iyah.23 Dasar yang digunakan adalah surat Al-T,alāk ayat 2. Sedangkan ketentuan Pasal 167, itu merupakan salah satu bentuk upaya pemerintah untuk menciptakan rujuk yang $m a^{\prime} r u f$ sebagaimana firman Allah :

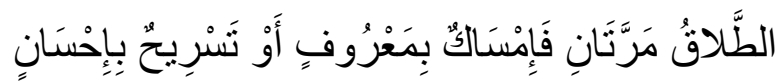

"Talak (yang dapat dirujuki) dua kali. setelah itu boleh rujuk lagi dengan cara yang ma'ruf atau menceraikan dengan cara yang baik" ${ }^{24}$

Pasal 168 KHI ditambahkan :

(1) Dalam hal rujuk dilakukan di hadapan Pembantu Pegawai Pencatat Nikah daftar rujuk dibuat rangkap 2 (dua), diisi dan ditandatangani oleh masing-masing yang bersangkutan beserta saksi- saksi, sehelai dikirim kepada Pegawai Pencatat Nikah yang mewilayahinya, disertai surat-surat keterengan yang diperlukan untuk dicatat dalam buku Pendaftaran Rujuk dan yang lain disimpan.

(2) Pengiriman lembar pertama dari daftar rujuk oleh Pembantu Pegawai Pencatat Nikah dilakukan selambat-lambatnya 15 (lima belas) hari sesudah rujuk dilakukan.

(3) Apabila lembar pertama dari daftar rujuk itu hilang, maka Pembantu Pegawai Pencatat Nikah membuatkan salinan dari daftar lembar kedua,dengan berita acara tentang sebab-sebab hilangnya. ${ }^{25}$

Lebih jauh dari itu di dalam Pasal 169 juga dinyatakan :

(1) Pegawai Pencatat Nikah membuat surat keterangan tentang terjadinya rujuk dan mengirimkannya kepada Pengadilan Agama ditempat berlangsungnya talak yang bersangkutan, dan kepada suami dan

\footnotetext{
${ }^{22}$ Q.S. al-Baqarah, $2: 282$.

${ }^{23}$ Al-Jazīrī, Al-Madhāhib Al-Arba'ah, Vol. 4, hlm. 333. Lihat juga Ibn Rusyd, Bidāyah, hlm. 63

24al-Qur'an, 2 : 229.

${ }^{25}$ KHI Pasal 168, lihat juga Permenag No 3 Tahun 1975 tentang Kewajiban Pegawai Pencatat Nikah dan Tata Kerja Pengadilan Agama dalam melaksanakan Peraturan Perundang-undangan Perkawinan bagi yang beragama Islam Pasal 33.
} 
isteri masing-masing diberikan Kutipan Buku Pendaftaran Rujuk menurut contoh yang ditetapkan oleh Menteri Agama.

(2) Suami isteri atau kuasanya dengan membawa Kutipan Buku Pendaftaran Rujuk tersebut datang ke Pengadilan Agama di tempat berlangsungnya talak dahulu untuk mengurus dan mengambil Kutipan akta Nikah masing-masing yang bersangkutan setelah diberi catatan oleh Pengadilan Agama dalam ruang yang telah tersedia pada Kutipan Akta Nikah tersebut, bahwa yang bersangkutan benar telah rujuk.

(3) Catatan yang dimaksud ayat (dua) berisi tempat terjadinya rujuk, tanggal rujuk diikrarkan, nomor dan tanggal Kutipan Buku Pendaftaran Rujuk dan tanda tangan Panitera. ${ }^{26}$

Ketentuan yang ada pada Pasal 168 dan Pasal 169 KHI, semua itu diatur untuk mewujudkan keadilan dalam masyarakat. ${ }^{27}$ Cara yang dilakukan pemerintah adalah membuatkan Kutipan Bukti Pendaftaran Rujuk, sebab bila perkawinan bisa dibuktikan dengan menggunakan Akta nikah, maka rujuk juga harus ada buktinya, yakni dengan menggunakan Kutipan Bukti Pendaftaran Rujuk. Mengenai dasarnya sebagaimana keterangan sebelum yang menjelaskan tentang pentingnya sebuah pencatatan dalam masalah perkawinan dan rujuk.

Adapun hak istri dalam rujuk dipaparkan dalam Kompilasi Hukum Islam di terangkan pada bab XVIII pasal 163, 164, 165, dan 166.28

\section{Pasal 163}

(1) Seorang suami dapat merujuk isterinya yang dalam masa iddah.

(2) Rujuk dapat dilakukan dalam hal-hal:

a. Putusnya perkawinan karena talak, kecuali talak telah jatuh tiga kali atau talak yang dijatuhkan qabla al-dukhul.

b. Putusan perkawinan berdasar putusan pengadilan dengan alasan atau alasan-alasan selain zina dan khuluk. ${ }^{29}$

Isi dari pasal $163 \mathrm{KHI}$ merupakan sebuah rumusan dari beberapa pengertian ulama fikih tentang rujuk, sebagaimana yang telah diterangkan pada pembahasan sebelumnya. Sehingga ada sebuah kesimpulan mengenai beberapa batasan-batasan tentang rujuk yakni :

a. Rujuk hanya bisa dilakukan pada masa iddah;

\footnotetext{
${ }^{26}$ KHI Pasal 169, lihat juga Permenag No 3 Tahun 1975 tentang Kewajiban Pegawai Pencatat Nikah dan Tata Kerja Pengadilan Agama dalam melaksanakan Peraturan Perundang-undangan Perkawinan bagi yang beragama Islam Pasal 34.

${ }^{27}$ Rofiq, Hukum Perdata, hlm. 258

${ }^{28}$ Rofiq, Hukum Islam, hlm. 320

${ }^{29} \mathrm{KHI}$, Pasal 163.
} 
b. Rujuk hanya dapat dilakukan pada talak raj'i, bukan talak tiga atau talak bāin;

c. Keadaan istri telak disetubuhi sebelum di talak;

d. Istri tidak diperkenankan meminta 'iwad atas perpisahan yang disebabkan talak, karena bila meminta 'iwad itu dinamakan khulu'.

Dan dasar yang digunakan dari pasal 163 ayat (1) KHI adalah surat Al-Baqarah ayat 228, sebagai mana keterangan yang sebelumnya. 30 Sedangkan untuk ayat (2) poin (a) dasarnya adalah surat Al-Baqarah ayat 230. ${ }^{31}$ Yaitu :

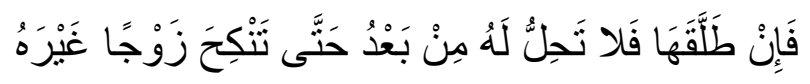

"Kemudian jika si suami mentalaknya (sesudah Talak yang kedua), Maka perempuan itu tidak lagi halal baginya hingga Dia kawin dengan suami yang lain". ${ }^{32}$

Sebagaimana pendapat Al-Maraghī dalam kitab tafsirnya, beliau menjelaskan bahwa hikmah dari pensyaratan istri yang sudah ditalak tiga untuk menikah dengan orang lain terlebih dulu, bila mana suaminya menginginkan kembali, adalah sebagai tanda bahwa konsekwensi dari talak tiga, itu menyebabkan laki-laki tersebut sudah tidak halal lagi bagi perempuan. ${ }^{33}$ Sehingga peranan laki-laki menjadi suami benar-benar telah habis, dan peranan tersebut digantikan dengan suami perempuan yang baru.

Sedangkan untuk pasal 163 ayat (2) poin (b), dasarnya adalah sebuah hadis. ${ }^{34}$

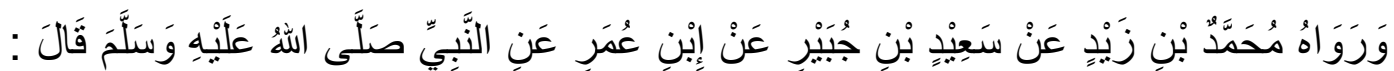

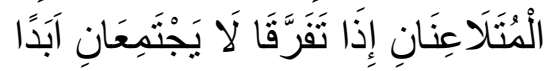

Diriwayatkan dari Muhammad bin zaid dari Sa'id bin jubair, dari Ibn Umar, dari Nabi Muhammad SAW beliau bersabda : "Seseorang yang sudah saling sumpah li'an, apabiila berpisah maka tidak bisa berkumpul selamanya". 35

Prosesi rujuk hampir sama dengan nikah, oleh karenanya dalam prosesi rujuk juga diharuskan adanya pesetujuan seorang istri dan

\footnotetext{
${ }^{30}$ Al-Jazīrī, Al-Madhāhib Al-Arba'ah, Vol. 4, hlm. 329

${ }^{31}$ Departemen Agama, Alasan Syar'i, 129. Lihat juga Sayyid Sābiq, Figh al-Sunnah, Vol 2 (Mesir: Dār al-Fatḥ, 2009), hlm. 177

32al-Qur'an, $2: 230$.

${ }^{33}$ Ahmad Muśțafā Al-Maraghī, Tafsìr Al-Maraghī, Vol 1 (t.t: Dār al-Fikr, t.th), hlm. 224

${ }^{34}$ Departemen Agama, Alasan Syar'i, 129.

${ }^{35}$ Aḥmad Bin Al-Husain, Al-Sunan Al-Şahīr Lil Baihaqi, Vol 3 (Pakistan: Dār al-Nashar, 1989), hlm. 144
} 
disaksikan oleh dua orang saksi dihadapan Pegawai Pencatat Nikah. Dan hal itu tertuang dalam pasal 164 dan 165 KHI. ${ }^{36}$

\section{Pasal 164}

Seorang wanita dalam iddah talak raj'i berhak mengajukan keberatan atas kehendak rujuk dari bekas suaminya dihadapan Pegawai pencatat Nikah disaksikan dua orang saksi. ${ }^{37}$

\section{Pasal 165}

Rujuk yang dilakukan tanpa persetujuan bekas istri dapat dinyatakan tidak sah dengan putusan Pengadilan Agama.38

Pembuktian rujuk harus dengan kutipan Buku Pendaftaran Rujuk dan bila mengalami kerusakan maka harus memproses kepada instansi yang bersangkutan, sehingga muncullah rumusan pasal 166 KHI. ${ }^{39}$

\section{Pasal 166}

Rujuk harus dapat dibuktikan dengan Kutipan Buku Pendaftaran Rujuk dan bila bukti tersebut hilang atau rusak sehingga tidak dapat dipergunakan lagi dapat dimintakan duplikatnya kepada instansi yang mengeluarkan semula. ${ }^{40}$

\section{Hak istri dalam rujuk prespektif Maqasid al-Shariáh}

Secara etimologi, maqasid adalah bentuk plural (jamak) dari kata maqsad yang berarti sesuatu yang dituju atau tujuan yang ingin dicapai. Kata al-Shariáh berarti tempat mengalirnya air. ${ }^{41}$ Secara terminologis shariáh adalah hukum-hukum Allah yang diperuntukkan kepada manusia yang berisi tentang kebijaksanaan dan kesejahteraan dalam kehidupan di dunia dan di akhirat. Dengan demikian, aturan apapun yang menggantikan keadilan dengan ketidakadilan, belas kasih, dengan lawan, kebaikan bersama dengan kejahatan atau kebijaksanaan dengan omong kosong adalah aturan yang tidak termasuk dalam Shariáh, meskipun jika hal itu diklaim oleh para mufassir.

Sedangkan secara terminologi, kata Maqasid al-Shariáh adalah tujuan, nilai dan faidah yang ingin dicapai dari diturunkannya shariáh baik secara global maupun secara terperinci. ${ }^{42}$ Menurut Jasser Audah, maqasid alshariáh adalah cabang ilmu keislaman yang menjawab segenap pertanyaan-pertanyaan yang sulit dan diwakili oleh sebuah kata yang

\footnotetext{
${ }^{36}$ Rofiq, Hukum Islam, hlm. 321

${ }^{37}$ KHI Pasal 164.

${ }^{38}$ KHI Pasal 165.

${ }^{39}$ Rofiq, Hukum Islam, hlm. 323

40Martiman, Hukum Perkawinan, hlm. 187

41 Ahmad al-Raisuni, hlm. 13

42 Ahmad al-Raisuni, hlm. 14
} 
tampak sederhana, yaitu "mengapa?", seperti beberapa pertanyaan berikut? Mengapa seorang muslim sholat? Mengapa zakat dan puasa merupakan salah satu rukun Islam? Mengapa berlaku baik terhadap tetangga merupakan kewajiban dalam Islam? Mengapa minum-minuman beralkohol walaupun sedikit adalah dosa besar dalam Islam? Mengapa hukuman mati diterapkan bagi orang yang memperkosa atau membunuh secara sengaja? ${ }^{43}$

Jasser menambahkan bahwa maqasid al-shariáh adalah sejumlah tujuan yang baik yang diusahakan oleh shariát Islam dengan cara memperbolehkan atau melarang suatu hal. Maqasid al-shariáh juga berarti sejumlah tujuan ilahi dan konsep akhlak yang melandasi proses altasyri'al-Islami (penyusunan hukum berdasarkan shari'at Islam), seperti prinsip keadilan, kehormatan manusia, kebebasan kehendak, kesucian, kemudahan, kesetiakawanan dan lain sebagainya. ${ }^{44}$

Khusus bab pernikahan, salah seorang pakar Maqasid al-shariáh, Jamaluddin Atiyyah, menjelaskan secara rinci tentang Maqasid atau tujuan dari penshariatan pernikahan (keluarga) dengan cara memahami dan menafsirkan teks al-Qur'an dan sunnah tentang Maqasid al-shariáh pernikahan, serta memadukan beberapa pendapat dari pakar Maqasid lainnya. Menurut Jamaluddin Atiyyah, Maqasid al-shariáh dari pernikahan adalah:

1. Mengatur hubungan laki-laki dan perempuan

Pernikahan dalam Islam datang sebagai koreksi terhadap bentuk pernikahan di Arab sebelum datangnya Islam yang dianggap tidak mencerminkan nilai-nilai kemanusiaan. Pernikahan sebelum Islam memposisikan manusia layaknya binatang, apalagi kedudukan seorang perempuan yang jauh di bawah kedudukan laki-laki. Hadirnya pernikahan Islam membawa angin segar terutama bagi kalangan perempuan, di mana Islam menganggap laki-laki dan perempuan sama, mempunyai hak dan kewajiban yang seimbang sebagai suami dan istri.

Pernikahan Islam menjelaskan beberapa aturan yang berkaitan dengan hubungan suami istri, seperti anjuran untuk menikah dan larangan membujang, aturan tentang poligami, aturan tentang talak,

\footnotetext{
${ }^{43}$ Jasser Auda, maqasid al-Shariáh:A Beginner's Guide, terjemah oleh Áli Abdelmoním, alMaqasid untuk pemula (Suka Press, tk; tt), hlm. 4

${ }^{44}$ Jasser Auda, Maqasid al-Shariáh.... hlm. 4-5
} 
aturan tentang larangan berzina, aturan tentang khulu', fasakh, dan aturan lainnya yang tidak pernah dikenal sebelumnya, atau kalaupun sudah aturan, dirasa belum memposisikan suami dan istri secara seimbang sehingga sering terjadi ketidakadilan dalam pola hubungan keluarga. ${ }^{45}$

Peneliti menilai, bahwa dalam aturan fikih ulama empat mazhab sepakat tentang hak rujuk itu hanya milik suami sedangkan istri tidak memiliki hak sama sekali, sehingga dalam pelaksanaannya meskipun rujuk tanpa mendapatkan izin dari istri maka itu masih dianggap sah, karena rujuk merupakan hak prioritas seorang suami. ${ }^{46}$ Sedangkan dasar yang digunakan adalah firman Allah surat Al-Baqarah ayat 228. ${ }^{47}$ Akan tetapi, apabila difahami secara utuh mengenai aturan pernikahan sendiri, maka akan ditemukan aturan tentang khuluk, yang mana apabila istri tidak berkenan untuk melanjutkan hubungan rumah tangga dengan suaminya maka ia boleh mengakhirinya melalui jalur aturan khuluk. ${ }^{48}$ Aturan itu berbeda dengan aturan pernikahan yang terdapat di Indonesia, dalam UU Tahun 1974 tentang Perkawinan maupun KHI, tidak ada aturan yang menjelaskan tentang adanya hak khuluk bagi istri, sehingga sangat wajar apabila dalam bab Rujuk pasal $165 \mathrm{KHI}$ ada pengembangan ketentuan yakni istri memiliki peluang untuk menolak kehendak rujuk suami, sebab hak mereka untuk melakukan khuluk tidak ada.

Ketentuan itu apabila dikaji dalam keilmuan kaidah fikih, maka sesuai dengan kaidah:

$$
\text { إِذَا ضَاقَ الْأَمْرُ اتَََّعَ و إِذَا انَّسَعَ ضَاقَ }
$$

"Apabila sempit, maka ia menjadi luas dan apabila luas menjadi sempit." 49

Hal ini menunjukkan bahwa sedikit banyaknya kebiasaan umat pada masa dan di tempat diturunkannya al-Qur'an mempengaruhi hukum yang terbentuk (Sosiologi Antropologi Hukum Islam)

\footnotetext{
45 Jamaluddin 'Atiyyah, Nahwa Taf'il Maqasid Shari'ah, (Damaskus; Dar al-Fikr; 2001), hlm. 149

${ }^{46}$ Imām Shamsu al-Dīn abu Bakar Muhammad, Al-Mabsuţ li al-Sarkhasi, Vol 5 (Lebanon : Beirut, 2000), hlm. 270

${ }^{47}$ Al-Jazīìi, hlm. 331

${ }^{48}$ Khuluk adalah perceraian yang terjadi atas permintaan istri dengan memberikan tebusan atau iwadh kepada dan atas persetujuan suaminya.

49 Muhammad shidqī ibn Ahmad, Al-Wajīz fì ìdhoh qawaid al-figh al-kulliyah, (Bairut: Muassasah al-risālah), hlm. 232-231
} 
termasuk dalam ketentuan rujuk. Aturan-aturan hukum bagi laki-laki dan perempuan yang sedang menjalani hidup rumah tangga yang tertuang dalam fiqih munakahat tentu memiliki relevansi dengan salah satu kemaslahatan yang ingin dicapai atau kemudaratan yang hendak dihindarkan. Di sisi lain maqasid Shari'ah dapat mempresentasikan hubungan antara hukum Islam dengan ide-ide terkini tentang hak-hak manusia, pembangunan dan peradaban.

Shari' dalam mewujudkan tujuan mengatur hubungan antara lakilaki dan perempuan itu mensyari'atkan berbagai hukum seperti halnya talak beserta syarat-syaratnya begitu juga dalam hal rujuk ini jelas diatur juga oleh syari'at sehingga nantinya bisa mewujudkan tujuan tersebut. 50

2. Menjaga keturunan

Nabi Muhammad menganjurkan umat Islam untuk memilih calon pasangan yang subur (bisa melahirkan anak) karena termasuk dari tujuan pernikahan adalah menjaga keturunan, artinya melahirkan anak sebagai penerus perjuangan orang tuanya. Menjaga keturunan berarti menjadikan anak laki-laki sebagai seorang ayah dan seorang perempuan sebagai seorang ibu. Tujuan menjaga keturunan ini menjadi sangat penting demi keberlanjutan kehidupan manusia.

Oleh karena itu, ada beberapa aturan yang tujuannya agar menjaga keturunan ini tetap terealisasi, diantaranya adalah keharusan menikah dengan lain jenis (laki-laki dengan perempuan) dan larangan menikah sesama jenis (laki-laki dengan laki-laki, dan perempuan dengan perempuan), adanya larangan mengeluarkan sperma di luar kelamin istri dengan alasan agar tidak punya anak, larangan membujang, larangan melakukan tindakan medis terhadap alat reproduksi perempuan agar terhindar untuk mempunyai anak, dan aturan lainnya. ${ }^{51}$

Ketika seorang suami merujuk istri sedangkan istri tidak bisa menolak atas ajakan rujuk tersebut maka akan berdampak terhadap hubungan antara suami dan istri sehingga hubungan tersebut menjadi tidak baik dan jika dalam menjalani kehidupan berkeluarga itu hubungan mereka tidak baik maka akan berdampak pada keinginan

${ }^{50}$ Jamaluddin 'Atiyyah, hlm. 149

51 Jamaluddin 'Atiyyah, hlm. 150 
untuk memiliki keturunan dan dampak tersebut merupakan hal yang berbahaya karena tujuan dalam rujuk tersebut tidak tercapai.

3. Menciptakan keluarga yang sakinah, mawaddah, wa rahmah

Tujuan pernikahan tidak sekedar untuk menyalurkan kebutuhan biologis semata, akan tetapi juga erat kaitannya dengan menciptakan kondisi psikologis yang tenang, damai, dan tentram dengan balutan cinta kasih sayang antara suami dan istri. Pernikahan menjadi pintu gerbang bagi suami dan sitri untuk saling mencurahkan kasih sayangnya satu sama lain sehingga perasaan tenang dan damai akan tercipta. Kalaupun ada konfilk, itu tidak lebih dari sekedar bumbu cinta yang akan mewarnai sedapnya romantisme berkeluarga.

Agar tujuan ini terealisasi, Islam mengatur pola hubungan suami istri yang dideskripsikan dengan "mu'asharah bi al-ma'ruf", yaitu memperlakukan suami atau istri dengan cara-cara terbaik yang tidak akan menyakiti kedua pasangan, Islam juga mengatur tata karama berhubungan seksual dan aturan lainnya. ${ }^{52}$

Hubungan antara suami dan istri tak terhitung dalam contoh secara nyata, syari'at pun telah mengingatkan bahwasanya antara suami dan istri hendaknya merasa tenang satu dengan yang lain sehingga terciptalah rasa kasih sayang diantara keduanya. ${ }^{53}$ Dalam pandangan al-Qur'an, salah satu tujuan pernikahan adalah untuk menciptakan sakinah, mawaddah, dan rahmah antara suami, istri dan anak-anaknya. ${ }^{54}$

Jika pernikahan dilaksanakan atas dasar mengikuti perintah agama dan mengikuti sunnah Rasul, maka sakinah, mawaddah dan rahmah yang telah Allah ciptakan untuk manusia dapat dinikmati oleh sepasang suami istri. Dalam mewujudkan tujuan diatas, syariat telah mengatur berbagai hukum tentang tatacara bergaul dan tatakrama dalam pernikahan. ${ }^{55}$

Terkait dengan istilah sakinah, mawaddah dan rahmah, memunculkan beragama definisi. Di antaranya adalah Al-Isfahan (ahli fiqh dan tafsir) mengartikan sakînah dengan tidak adanya rasa gentar dalam menghadapi sesuatu; Menurut al-Jurjani (ahli bahasa), sakînah

\footnotetext{
52 Jamaluddin 'Atiyyah, hlm. 150

53 Jamaluddin 'Atiyyah, hlm. 150

${ }^{54}$ Quraish Shihab, Keluarga Sakinah, Dalam Jurnal Bimas Islam, Vol. 4 NO. 1, Tahun 2011, 4.

${ }^{55}$ Jamaluddin 'Atiyyah, hlm. 150
} 
adalah adanya ketentraman dalam hati pada saat datangnya sesuatu yang tidak diduga, dibarengi satu nūr (cahaya) dalam hati yang memberi ketenangan dan ketentraman pada yang menyaksikannya, dan merupakan keyakinan berdasarkan penglihatan ('ain al-yaqin). Ada pula yang menyamakan sakînah itu dengan kata rahmah dan tuma'ninah, artinya tenang, tidak gundah dalam melaksanakan ibadah.

4. Menjaga garis keturunan

Menjaga garis keturunan berbeda dengan menjaga keturunan. Manjaga keturunan berarti pernikahan diharapkan akan melahirkan seorang anak dan menjadikan suami sebagai ayah dan istri sebagai ibu. Sedangkan menjaga garis keturunan, tidak sekedar melahirkan seorang anak, tapi melahirkan seorang anak dari pernikahan yang sah sehingga jelas garis keturunannya dan siap bapak ibu sahnya.

Untuk merealisasikan tujuan ini, Islam melarang keras perzinahan yang berakibat pada ketidakjelasan nasab seorang anak, Islam juga melarang mengadopsi anak dengan tujuan menjadikan anak angkatnya sebagai anak keturunannya sendiri, ada larangan menyembunyikan status anak dalam rahim, ada juga aturan tentang masa iddah, dan aturan lainnya. ${ }^{56}$

Dalam tata hukum Islam (Fikih), masalah ikatan darah atau keluarga menjadi masalah yang mempunyai dampak luas, karena dari tes itulah bisa diketahui nasab (keturunan keluarga atau silsilah). Silsilah tidak hanya berdampak pada masalah generatif semata, namun juga berdampak pada masalah hukum dan sosial. Para ulama fikih sepakat bahwa akad perkawinan yang sah merupakan sebab dalam ketetapan nasab seorang anak. ${ }^{57}$

Di dalam hukum Islam, nasab mempunyai peran yang sangat penting. Dengan jelasnya status nasab seseorang, hukum-hukum yang berkait dengan hal ini juga akan jelas. Semisal tentang perkawinan. Dengan kepastian bahwa seorang laki-laki mempunyai ikatan darah dan masih menjadi muhrim seorang perempuan, haram hukumnya bagi kedua orang ini untuk melakukan perkawinan atau untuk menentukan apakah seseorang itu berhak mendapat warisan dari orang yang telah meninggal. Kepastian nasab mempunyai peran yang

\footnotetext{
${ }^{56}$ Jamaluddin 'Atiyyah, hlm. 151

${ }^{57}$ Ahmad Farraj Husain, Ahkâm al-Usrah fi al-Islâm, (Beirut: Dâr al-Jami'iyyah, 1998), hlm. 248
} 
sangat vital, sebab dalam hukum Islam waris sudah diatur dengan tegas. Namun, mobilitas yang tinggi dari masyarakat, bisa membuat dua orang bersaudara yang masih muhrim tidak saling kenal. Bisa karena jarak yang memisahkan atau karena alasan lain sehingga mereka memang tidak saling kenal.

5. Menjaga keberagaman dalam keluarga

Tujuan ini sangat jelas ketika membahas tentang kriteria calon pasangan yang ideal untuk dijadikan pendamping hidup selamanya (suami atau istri). Nabi Muhammas saw. memberikan gambaran bahwa ada empat kriteria yang harus jadi pertimbangan ketika memilih calon suami-istri, yaitu sisi fisik, sisi keluarga, sisi ekonomi dan sisi agama. Ke-empat kriteria tersebut diharapkan menjadi pertimbangan kuat ketika memilih calon suami atau istri. Akan tetapi, dari ke-empat kriteria tersebut, hanya agam dan keberagamannyalah yang harus menjadi pertimbangan utama dibandingkan tiga kriteria lainnya. ${ }^{58}$

Dalam mewujudkan tujuan tersebut datanglah hukum-hukum syariat yang berkenaan dengan pertanggungjawaban pemimpin keluarga yakni mengajari istri dan anak-anaknya tentang akidah, ibadah dan akhlaq, ${ }^{59}$ seperti firman Allah Swt. dalam surat Thoha ayat 132:

$$
\text { وَأَمُرْ أَهْلَكَ بِالصنّلاةِ وَاصْطَبَرْ عَلَيْهَا }
$$

Dan perintahkanlah keluargamu melaksankan sholat dan sabar dalam mengerjakannya.

Dalam perkawinan, kepercayaan agama merupakan suatu landasan yang mengisi setiap jiwa, dan kehendaknya serta menentukan jalan kehidupan yang bakal ditempuhnya. Hal yang demikian itu masih banyak masyarakat yang terkecoh dalam masalah kepercayaan agama sehingga mereka menduga masalah kepercayaan agama ini hanyalah perasaan yang ada dalam jiwa dan dapat diganti dengan beberapa filsafat ataupun beberapa aliran sosial.

Banyak hal yang akan terjadi diakibatkan atas hilangnya keberagamaan dalam keluarga seperti kerusakan, buruknya pendidikan dan panutan dalam keluarga. ${ }^{60}$

${ }^{58}$ Jamaluddin 'Atiyyah, hlm. 153

59 Jamaluddin 'Atiyyah, hlm. 153

${ }^{60}$ Jamaluddin 'Atiyyah, hlm. 153 
6. Mengatur pola hubungan yang baik dalam keluarga

Berkeluarga berarti memasuki jenjang baru dari kelas kehidupan yang dialami oleh manusia. Sebelum berkeluarga, tidak banyak hak dan kewajiban yang dialami dan masih terkesan bebas melakukan apapun yang diinginkan. Setelah masuk pada jenjang berkeluarga, maka suami dan istri, begitu juga anak yang dilahirkan akan dihadapkan pada beberapa aturan yang merangkai pola hubungan natara anggota keluarga. Suami dan istri akan terikat pada hak dan kewajiban yang harus dipenuhi, begitu juga pola hubungan antara anak dan orang tua.

Berkeluarga juga berdampak pada lahirnya pola hubungan baru yang dilengkapi dengan aturan-aturan yang mengikat, seperti pola hubungan kekerabatan, pola hubungan mahrom, pola hubungan kewalian, dan pola hubungan lainnya yang oleh Islam diatur sedemikian rupa sehingga tidak ada ruang bagi anggota keluarga untuk melakukan tidak semena-mena yang jauh dari rasa keadilan dan kemaslahatan. ${ }^{61}$

Dalam hal pola hubungan yang baik bnyak sekali diatur dalam kewajiban suami kepada istri, kewajiban istri kepada suami, kewajiban anak kepada orang tua dan sebaliknya. ${ }^{62}$

7. Mengatur aspek finansial keluarga

Pernikahan Islam menjadi pintu masuk lahirnya aturan-aturan baru yang berkaitan dengan aspek finansial, seperti adanya kewajiban suami membari mahar keada istri sebagai bukti bahwa dia adalah lakilaki yang serius dan bertanggungjawab, suami juga punya kewajiban memberi nafkah kepada istri dan juga anak-anaknya, termasuk juga memberi nafkah untuk istri yang dicerai, memberikan upah bagi ibu susuan, adanya hukum kewarisa, hukum wasiat kepada kerabat, wakaf keluarga, perwalian harta, dan aturan lainnya yang berkaitan dengan aspek finansial. ${ }^{63}$

Ditinjau dari sisi sosiohistoris, ulama' fikih berpendapat bahwa suami berwenang penuh dalam melakukan rujuk. Menurut peneliti, ketentuan tersebut memang sesuai dengan kondisi waktu itu dan pendapat itulah yang terbaik untuk diterapkan di tengah masyarakat.

${ }^{61}$ Jamaluddin 'Atiyyah, hlm. 154

62 Jamaluddin 'Atiyyah, hlm. 154

${ }^{63}$ Jamaluddin 'Atiyyah, hlm. 154 
Sebab, setiap istri yang ditalak oleh suaminya, maka selama masa menunggu iddahnya, istri bertempat tinggal di rumah suaminya itu. Segala kebutuhan dan keperluannya dipenuhi mantan suaminya. Dengan demikian dalam segi finansial istri tercukupi walaupun dalam masa iddah.

\section{Penutup}

Berdasarkan hasil penelitian yang telah peneliti lakukan terkait dengan hak istri dalam rujuk, peneliti dapat menyimpulkan sebagai berikut:

1. Secara umum ulama fikih menjelaskan bahwa dalam rujuk tidak ada hak bagi istri ketika suami mengajukan rujuk.

2. Seiring dengan zaman hak istri diperhitungkan dalam hal rujuk supaya dapat merealisasikan tujuan-tujuan pernikahan (Maqasid alShari'ah)

\section{Daftar Pustaka}

Undang-Undang Peradilan Agama Dan Kompilasi Hukum Islam. Yogyakarta: Graha Pustaka, t.t.

Abu Bakar bin Ali. al-Jauharah al-nīrah. tt: al-Khoiriyah, 1322.

Aḥmad Bin Al-Husain. Al-Sunan Al-Şah̄̄r Lil Baihaqi. Vol 3. Pakistan: Dār al-Nashar, 1989.

Ahmad Farraj Husain. Ahkâm al-Usrah fi al-Islâm. Beirut: Dâr al-Jami'iyyah, 1998.

Ahmad Muș́țafā Al-Maraghī. Tafsīr Al-Maraghī, Vol 1. t.t: Dār al-Fikr, t.t.

Ahmad Rofiq. Pembaruan Hukum Islam di Indonesia. Yogyakarta: Gama Media, 2001.

. Hukum Perdata Islam Di Indonesia. Jakarta: Rajagrafindo Persada, 2013.

Amir Syarifuddin. Hukum Pernikahan di Indonesia antara Figh Munakahat dan Undang-undang Pernikahan. Jakarta: Kencana, 2006. Hukum Perkawinan Islam di Indonesia. Jakarta: Prenada Media, 2007.

Haris Herdiansyah. Metodologi Penelitian Kualitatif. Jakarta: Salemba Humanika, 2010.

Imām Shamsu al-Dīn abu Bakar Muhammad. Al-Mabsuț li al-Sarkhasi. Vol 5. Lebanon : Beirut, 2000.

Jamaluddin 'Atiyyah. Nahwa Taf'il Maqasid Shari'ah. Damaskus; Dar alFikr; 2001. 
Jasser Auda. Maqasid al-Shariáh:A Beginner's Guide, terjemah oleh Áli Abdelmoním, al-Maqasid untuk pemula. Suka Press, tk; tt.

Moh Rifa'i. Fiqih Islam Lengkap. Semarang : PT. Karya Toha Putra, 1978.

Muhammad Shidqī ibn Ahmad. Al-Wajiz fì ìdhoh qawaid al-figh al-kulliyah. Bairut: Muassasah al-risālah.

Muhāmmad bin Qashīm Al-Ghazī. Fath al-Qorìb. Surabaya: Nurul Huda, t.t.

Sayyid Sābiq. Fiqh al-Sunnah. Vol 2. Mesir: Dār al-Hadīś, 2009.

Suharsimin Arikunto. Prosedur Penelitian Suatu Pendekatan Praktik. Jakarta: PT RinekaCipta, 2006.

Quraish Shihab. Keluarga Sakinah, Dalam Jurnal Bimas Islam. Vol. 4 No. 1, Tahun 2011. 